\title{
The Orphan Decade: Elizabeth Bowen's 1930s Novels
}

\section{Anna Teekell}

\section{(2) OpenEdition \\ 1 Journals}

\section{Electronic version}

URL: http://journals.openedition.org/etudesirlandaises/5374

DOI: 10.4000/etudesirlandaises.5374

ISSN: 2259-8863

\section{Publisher}

Presses universitaires de Caen

\section{Printed version}

Date of publication: 29 November 2017

Number of pages: 139-151

ISBN: 978-2-7535-7388-8

ISSN: 0183-973X

\section{Electronic reference}

Anna Teekell, «The Orphan Decade: Elizabeth Bowen's 1930s Novels », Études irlandaises [Online], 42-2 | 2017, Online since 29 November 2017, connection on 13 September 2019. URL : http:// journals.openedition.org/etudesirlandaises/5374; DOI : 10.4000/etudesirlandaises.5374 


\title{
The Orphan Decade: Elizabeth Bowen's 1930s Novels
}

\author{
Anna TeEKell \\ Christopher Newport University
}

Abstract

This essay reads Elizabeth Bowen's major novels of the 1930s - all of which feature orphaned protagonists - as mimetic of a decade that has often been critically "orphaned" in literary history. Bowen's travelling orphans exemplify the problem of the political refugee in the 1930s, and her novels' deliberately unresolved endings demonstrate an unwillingness to look into a future that seemed already foreclosed. By examining the novels of this orphan decade, in which the characters as well as the prose are simultaneously arrested and on the move, this essay offers a reassessment of Bowen's novels' importance to the way we read the 1930s.

Keywords: Elizabeth Bowen, 1930s, orphans, refugees, travel.

\section{Résumé}

Cet essai interprète les principaux romans des années trente d'Elizabeth Bowen, dont chacun inclut quelques protagonistes orphelins, comme mimétiques d'une décennie souvent laissée "orpheline » dans l'histoire de la critique littéraire. Les orphelins itinérants de Bowen illustrent le problème du réfugié politique dans les années trente, et la fin délibérément non résolue de ses romans manifeste une réticence à envisager un avenir qui semble déjà déterminé. En examinant les romans de cette décennie orpheline, où les personnages, aussi bien que la prose, sont simultanément en arrêt et en mouvement, cet essai offre un correctif aux narratifs obsolètes de la littérature anglaise des années trente, ainsi qu'une réévaluation de l'importance des romans de Bowen pour la façon dont nous lisons cette décennie.

Mots-clés: Elizabeth Bowen, 1930s/les années trente, orphelins, réfugiés, déplacement.

It is by now a scholarly convention to open a discussion of Elizabeth Bowen with the problem of "placing" her. As Phyllis Lassner remarks in a 2010 review essay in Modernism/Modernity, "the critical dilemma has always been one of situating and stabilizing Bowen's ouvre and style in literary history and theory... in short, as a writer and as a person, Bowen's identity is a trouble-maker"”. Anglo-

1. Phyllis Lassner, "Out of the Shadows: The Newly Collected Elizabeth Bowen." Modernism/Modernity 17.3 (Autumn 2010): 670. I'd like to thank Phyllis for encouraging me to expand this essay, which began as a conference paper for the panel, “The 1930's: The Decade Modernism Forgot” at MLA in Chicago, 2014, and I'd like to thank the panel chair and organizer, Erica Delsandro, for her keen insight on this piece from conference paper to essay. I also thank Elka Shortsleeve for her help with my French. 
Irish, Bowen herself once remarked that she felt most at home in the middle of the Irish Sea, being seen as English in Ireland and Irish in England. Born in June 1899, she is half a generation older than "the Auden Generation" and not quite a generation younger than "The Pound Era", to contextualize by scholarly book title ${ }^{2}$. Her work has been categorized as a return to Jamesian psychological realism in the wake of Joyce and Woolf, and, conversely, as a dissolution of the novel itself ${ }^{3}$. She has been adopted as a darling of feminist criticism despite her own assertion, "I am not, and shall never be, a feminist". In short, Bowen's work - and the critical reception of it - has always troubled scholarly categories. As Luke Thurston writes in a 2013 special issue of Textual Practice, Bowen is an "exemplary artist of non-belonging 5". She seems to be, like so many of her characters, an orphan. And yet, for decades now, scholars have felt compelled to try to make her fit somewhere. I want to suggest in this essay that the conversation about placing Elizabeth Bowen is aligned with the conversation about placing 1930s fiction; her novels of the 1930s create an aesthetic that could only belong to that similarly orphaned decade.

Like the orphans who populate Bowen's novels, 1930s fiction seems to stick out of place. Critics are beginning to feel that, like a surplus child, something must be "done" about this writing. Like the orphan Pauline in To the North, Thirties fiction is, "responsive", "like a bear who you have to keep throwing buns at ${ }^{6 "}$. It responds to its historical moment stylistically, by the self-conscious deployment of modernist techniques, but a critical discourse that early mapped the 1930s as the decade of Auden and Orwell created an overdetermined assessment of Thirties writing as a reaction against a high modernism that was stylistically experimental and politically conservative. Thus, the 1930s was read, in its own moment, as the decade of the Group Theatre and the Left Book Club, of poetry of pylons and plain-style prose, assumed to be anti-Fascist as well as anti-Modernist. This designation - almost immediate and curiously longstanding - left little room for anything outside its parameters, and the consciously modernist fiction of the decade was left in a sort of no-man's-land of literary history ${ }^{7}$.

2. See Samuel Hynes' The Auden Generation: Literature and Politics in England in the 1930's, New York, Viking, 1977, and Hugh Kenner's The Pound Era, Berkeley, University of California P, 1971.

3. See Hermione Lee's Elizabeth Bowen: An Estimation (London: Vision, 1981), and Andrew Bennett and Nicholas Royle's Elizabeth Bowen and the Dissolution of the Novel: Still Lives, New York, St. Martin's Press, 1995.

4. Quoted in Maud Ellmann, Elizabeth Bowen: The Shadow Across the Page, Edinburgh, Edinburgh UP, 2004$), 18$.

5. Luke Thurston, “Double Crossing: Elizabeth Bowen's Ghostly Short Fiction”. Textual Practice 27.1 (2013): 9.

6. Bowen. To The North, New York, Anchor, 2006, 43. Hereafter abbreviated thus: (TN, 43).

7. Though the real canonization of the "revolutionary" 1930 s came in the similarly revolutionary 1960 s, the writers of the 1930s were adept at self-canonization before the end of the decade. See Louis MacNeice, Modern Poetry, Oxford, OUP, 1938, Muggeridge, Malcolm, The Thirties, London, Hamish Hamilton, 1940, Francis Scarfe, Auden and After: The Liberation of Poetry, 1930-1941, London, Routledge, 1941 and Stephen Spender, The Destructive Element: A Study of Modern Writers and Beliefs, London, Cape, 1935. 
What the literary history of Thirties prose became, in fact, was a no-woman'sland, for a focus on Great War memoirs and left-wing, Spanish Civil War-related prose left little room for "lady novelists", unless bookcased as Modernist Women (like Woolf and Stein) or demoted to the "middlebrow". The twinned fallacies that modernism was apolitical and that the political writing of the 1930s was antimodernist has meant that both the modernist stylistics and deep political awareness underscoring much 1930s fiction has been overlooked. Bowen's novels of the Thirties are both modernist in style and politically aware, and it is for these very reasons that they are so important to the literary history of the decade. The orphaned Elizabeth Bowen is indicative of the 1930s because she fits no ready-made categories. She demands our critical attention precisely because she is so difficult to account for.

Bowen's 1930s novels trouble the narrative of Irish literary history by appearing to flout both the Gaelic Revival and the anti-revival realism of Seán O'Faoláin and Frank O'Connor, and by being, like their author, seemingly parttime Irish. Her 1930s novels trouble the narrative of English literary history by being resolutely patrician and by appearing - on the surface - neither modernist enough to be Woolvian nor realist enough to be Red. Her carefully articulated worlds might be classed as realist comedies of manners (they are often comic, and everyone behaves nicely), but in this their subject matter elides Bowen's modernist practices. Her 1930s novels rely on formal devices learnt from Woolf and Joyce, and her characters are infatuated with the modernist trappings of the age of speed. Moreover, Bowen's prose is carefully wayward, sometimes to the point of opacity, and her characters constantly fret over their inability to articulate themselves. All these are telltale indications of her conscious engagement with the work of high modernism. Thinking through Bowen's 1930s novels, we begin to see that rather than obscuring the relationship between modernism and 1930s literature in Britain, Bowen's acute historical consciousness of the decade in which she was writing elucidates that link. In 1935's The House in Paris, Karen tells her aunt, "I wish the Revolution would come soon; I should like to start fresh while I am still young, with everything that I had to depend on gone" the historical consciousness of the decade - and then winks: Of course, "I shall always work against it", the upper-class Karen explains, "But I should like it to happen in spite of me" (HP 87).

Elizabeth Bowen's career spans the middle 50 years of the twentieth century. She published 10 novels, half of them between 1929 and 1938. In the course of

8. Two important correctives to the old, male-centered 1930s narrative are Maroula Joannou's edited collection, Women Writers of the 1930s: Gender, Politics and History, Edinburgh, Edinburgh University Press, 1999 and Jan Montefiore's Men and Women Writers of the 1930s: The Dangerous Flood of History, London, Routledge, 1996. 9. Elizabeth Bowen, The House in Paris, New York, Anchor, 2002, 87. Hereafter abbreviated thus (HP, 87). 
this decade, Bowen transformed from promising young "lady novelist" to a prolific, best-selling author, and yet, her name springs rarely to the lips when the term "Thirties Writer" comes about ${ }^{10}$. Here she is, a major writer, the bulk of her major work produced in the 1930s, but because she doesn't fit the narrative, she is left a sort of critical orphan. Four out of Bowen's five novels of the decade, The Last September (1929), To the North (1932), The House in Paris (1935) and The Death of the Heart (1938) all feature orphans as protagonists. The figure of the orphan in these texts: parentless, placeless, always young, always demanding to be accounted for, is also a figure for the 1930s as a lived decade and the 1930s as a self-conscious literary period ${ }^{11}$.

Nels Pearson has recently argued for a reading of Bowen as a postcolonial cosmopolitan writer, whose novels reveal the postcolonial expatriate's "unresolved status of... prior national belonging: the feeling that one has yet to belong to a stable consensus of nationhood ${ }^{12}$ ". Reflecting this vexed sense of national belonging, many of Bowen's novels are also temporally vexed, "shot through by the contrary notion that historical time and traditional social orders are merely interrupted and are still moving toward coherence ${ }^{13}$ ". The orphans who populate Bowen's Thirties novels are exemplary of these twinned problematics of time and space - from 18-year-old Lois Farquhar's Anglo-Irish suspended animation in The Last September to Portia Quayne's peripatetic adolescence in The Death of the Heart, "displacement is the norm of the present, but it has also been the norm of the past ${ }^{14}$ ". Pearson writes, "Bowen heroines are usually in process of negotiating belonging... it is not that they once belonged somewhere else and suddenly feel adrift in the globe-as-universe; rather, they always 'belong somewhere else”

10. Accounts of the Thirties as a literary decade usually center on Isherwood, Auden, Orwell, Waugh, Greene, Day-Lewis. Recharting the Thirties, edited by Patrick Quinn, London, Associated University Presses, 1996; includes an essay on Bowen's early mentor Rosamond Lehmann, and renee hoogland's essay on Bowen's Friends and Relations. See also Rewriting the Thirties: Modernism and After. Ed. Keith Williams and Steven Matthews, New York, Routledge, 1997.

11. Bowen uses an orphan protagonist again in her final novel, Eva Trout, London, Cape, 1969. I have written about Eva Trout and the Anglo-Irish Gothic in "Elizabeth Bowen and the Orphan Eva Trout," in Founder to Shore: Cross-Currents in Irish and Scottish Studies. Ed, Shane Alcobia-Murphy, Aberdeen, AHRC Centre for Irish and Scottish Studies, 2011.

12. Pearson, "Elizabeth Bowen and the New Cosmopolitanism" Twentieth-Century Literature 56.3 (Fall 2010): 322.

13. Pearson, Irish Cosmopolitanism, Gainesville, University of Florida Press, 2015), p. 84. Pearson explains that "Irish cosmopolitanism" stems from the overdetermination of national identity during Ireland's long decolonization, the related postponement and obscuring of Irish international and transnational identity, and the resulting need (or ability) to interlace one's still-forming Irish identity with one's often capacious global perspective. Its aesthetic of orientation is not merely double, or happening on two scales, but doubly transformative. Resisting the closure of Irish backgrounds even as it looks beyond them, it also defies historically absolute and geographically abstract images of modern dislocation by depicting extranational experiences that remain suffused with questions of unresolved origin (84).

14. Pearson, "Elizabeth Bowen and the New Cosmopolitanism", p. 324. 
(324-5). In no characters is this rendered more explicit than in Bowen's cadre of orphans. I contend that this sense of orphaned unbelonging in Bowen's Thirties novels is definitively linked to the sense of temporal dislocation brought on by the decade that Graves and Hodge called "the long week-end" - a period defined less by its own lights than by its position between two more actual events - the world wars $^{15}$. Bowen's Thirties orphans are lost in place as well as time; like the decade itself, they seem trapped or in transit, waiting for the next thing to happen.

The Death of the Heart focuses on the installation of Portia, Thomas' orphaned half-sister by his father and his father's mistress, at Thomas and Anna Quayne's home on Regent's Park. The nature of her birth has made Portia a lifelong expatriate, since her father lost his home and his place in society when he (grudgingly) left his wife for Portia's pregnant mother and an itinerant life in off-season continental hotels. "Nothing that's hers ever seems... to belong to her", remarks Anna; "it may be because they always lived in hotels" (DH 6). In fact, Anna says to her friend St. Quentin, "She's made nothing but trouble since before she was born". "You mean", he responds, "it's a pity she ever was?" (DH 7). Portia is presented as a problem to be solved, indeed, a pity. In this, she is not unlike scores of other literary orphans cast, with better or worse luck, upon the pages of so many nineteenth-century novels. But Portia's orphaned disposition, in 1938, has a particularly dark edge to it. She bears a "suggestion", the narrator explains, "of scared lurking... like a kitten that expects to be drowned" (DH 47). Indeed, her deportment is disconcerting for this very reason: "Portia had learnt one dare never look for long. She had those eyes that seem to be welcome nowhere, that learn shyness from the alarm they precipitate. Such eyes are always turning away or being humbly lowered - dare come to rest nowhere but on a point in space; their homeless intentness makes them appear fanatical" (DH 58). Arriving from the Continent into London in 1938, keeping her eyes to the ground, nothing of her own to her name - Portia maps not just onto the literary history of the orphan but onto the political history of the refugee.

When she appears at Major Brutt's hotel at the end of the novel, "Portia seemed to belong nowhere, not even here. Stripped of that pleasant home that had seemed part of her figure... she looked at once harsh and beaten, a refugee frightening, rebuffing all pity that has fear at the root" (DH 385). This depiction, with its twining of pity and fear, deliberately recalls the plight of the approximately 80,000 refugees who poured into Britain from the Nazi-occupied Continent between 1933 and the end of the Second World War ${ }^{16}$. Anna's reception of Portia

15. Robert Graves and Allan Hodge, The Long Week-End: A Social History of Great Britain 1918-1939, New York, Norton, 2001).

16. Louise London, Whitehall and the Jews, 1933-1948: British Immigration Policy, Jewish Refugees and the Holocaust, Cambridge, CUP, 2001. 
maps onto the British reaction to foreign, mostly Jewish refugees in the 1930s: Portia represents an alien interruption into Anna's carefully constructed habitat, she represents a drain on household economy, and she functions - through her diary, which Anna reads - as a sort of foreign observer of the Quayne world. Portia moves carefully in Anna's home, "crabwise, as though the others were royalty, never quite turning her back on them - and they, waiting for her to be quite gone, watched" (DH 32). As much as Portia fears Anna, her older sisterin-law fears her. The welcome she receives - so much more concerned about her inability to assimilate, her 'tainted' bloodline as Mr Quayne's bastard, her penury, than her actual wellbeing - is reminiscent of the unwilling "welcome" that the British public - and the Home Office - gave to European refugees ${ }^{17}$.

In 1935's The House in Paris, Bowen makes the connection between orphan and refugee overt by making the orphaned Leopold Jewish ${ }^{18}$. By 1938, when The Death of the Heart was published, she didn't need to; the same year saw the formation of the Intergovernmental Committee for Refugees. To do more than compare Portia to a refugee would be heavy-handed at the expense of the novel. In 1938, Penguin brought out its first two dozen "Specials", three of which deal explicitly with the refugee crisis. One was Norman Angell and Dorothy Buxton's You and the Refugee, which argues for the ethical imperative of admitting and assimilating refugees, and might well serve as an alternate title for The Death of the Heart ${ }^{19}$. Portia may be merely a social refugee, but the mixture of pity and fear with which she is received - the sense that Portia is not just an inconvenient ethical obligation but a potentially subversive one - makes her, at the very least, a figure emblematic of a political refugee ${ }^{20}$.

Portia is not unaware of her historical moment, nor of her position in the Quayne household. At one point, having been sent away from Anna's drawing room, she says to her older brother, "I do think history is sad". He responds,

17. Ibid.

18. With a Protestant mother and a Jewish father, Leopold would not be considered Jewish under Jewish law, but he is considered Jewish by everyone in the novel - as he would have been by the Nuremberg Laws, which the Nazis enacted the year the novel was published. See Note 28.

19. Norman Angell and Dorothy Buxton, You and the Refugee, London, Penguin, 1938. Angell's argument was, essentially, that to refuse aid to Jewish refugees was to commit moral and economic suicide. See also Louis Golding, The Jewish Problem, London, Penguin, 1938 and Phyllis Bottome, The Mortal Storm, London, Penguin, 1938.

20. Bowen's social circle would have made her well aware of the plight of refugees in Britain. She was particularly close friends with the philosopher Isaiah Berlin, a prominent member of the Jewish community, whose family emigrated from Riga after the Russian Revolution. Bowen also corresponded regularly with her cousin Hubert Butler, who was Ireland's chief advocate for admitting Jewish refugees, and was personally responsible for saving many lives. See Victoria Glendinning, Elizabeth Bowen: Portrait of a Writer, London, Weidenfeld and Nicholson, 1997, and Michael Ignatieff, Isaiah Berlin, New York, Henry Holt, 1998. 
More, shady... bunk, misfires and graft from the very start. I can't think why we make such a fuss now: we've got no reason to expect anything better. But at one time, weren't people braver? Tougher, and they didn't go round in rings. And also there was a future then. You can't get up any pace when you feel you're right at the edge. (DH 36)

Thomas' view of the present moment - "right at the edge" - is in tune with the dominant consciousness in Britain in the late 1930s, with groups like the British Union of Fascists, as Thomas might say, "going round in rings". The past may be sad, but "there was a future then" that doesn't seem possible for the characters in The Death of the Heart. For Thomas, this is a historical point, but it also foreshadows Portia's own plot, on a literary level. She has no future, because the novel will end before the reader even knows if she will go "home" to the cold Anna and Thomas or remain a refugee in the Karachi Hotel ${ }^{21}$.

Strikingly, none of Bowen's 1930s orphan novels comes to a satisfying conclusion. In each novel, the orphan's fate is implied but never conclusively "solved". If the orphans of the nineteenth century novel, the orphans of the gothic (a genre which suffuses Bowen's work) are generally solvable problems, characters who, by the end, tend to acquire family solidity or a safe haven, Bowen's 1930s orphans are left hanging in the balance. Unsatisfying and even tragic endings are implied for them, but the novels' actual conclusions look askance: in this, Bowen's orphan decade enacts a sort of aesthetic for the "low, dishonest decade" which was always certain to end in the conflagration that no one wanted to $\mathrm{see}^{22}$.

In The House in Paris, Max, an Anglo-French Jew, makes this remark about his English lover's rhetorical aesthetic:

Nowadays the world is in bad taste; it is no longer "history in the making", or keeps rules or falls in with nice ideas. Things will soon be much more than embarrassing; I doubt if one will be able to save one's face. Humour [is] no longer possible. Karen will have to find herself something else. (HP 120)

What Max means is that she must find some other vehicle for expression. Karen, in an answer that seems to predict Paul Fussell's thesis in The Great War and Modern Memory, responds, "Irony seems less childish, I daresay ${ }^{23 "}$ (HP 120). In any case, to meet the times, something in her very language would have to shift. One of the perpetual troubles in Bowen's 1930s novels is the deployment

21. The Karachi Hotel appears to cater to ex-colonial civil servants and officers, and as such it represents the longterm physical and spiritual homelessness engendered by British imperialism.

22. W.H. Auden, "September 1, 1939." The English Auden, London, Faber, 1988.

23. Paul Fussell contends that irony becomes "the appropriate interpretive means" for language and history during and after the Great War, The Great War and Modern Memory, New York, Oxford University Press, 1975, p. 3. 
of a language commensurate with the history of the moment. Puzzling over how to express herself in a letter, Emmeline in To the North suggests, "Perhaps some day words will be different or there will be others" (TN 125). "Often when she spoke", the narrator of The House in Paris says of Karen's friend Naomi, "she seemed to be translating, and translating rustily. No phrase she used was what anyone could quite mean; they were doubtful, as though she hoped they would do" (HP 6). An astute reader of Flaubert, Bowen came of age as a writer knowing that the mot juste would always be a mirage. Her characters seem afflicted with the same problem. As Max tells Karen, "What I say is correct, but never spontaneous, is it? It is too tight or too loose; it never fits what I mean... What I say would often be right if I meant something else" (HP 127). By making both Max and Naomi Anglo-French, Bowen emphasizes the difficulties of communication, but their bilingualism merely magnifies the linguistic problem faced by all of Bowen's characters ${ }^{24}$.

One of the hallmarks of her writing and the criticism of it is Bowen's prose, which was once frequently accused by numerous critics of a sort of linguistic failure to thrive. Opaque, baroque, given to twists and turns, her sentences often seem to struggle to say what they mean. This stylistic signature is now readable as a positive part of Bowen's modernist difficulty, a language dilemma that is shared between her readers and her characters. Consider the opening lines of both To the North and the House in Paris. To the North begins,

Towards the end of April a breath from the north blew cold down Milan platforms to meet the returning traveler" (TN 1, emphasis added) The House in Paris opens, In a taxi skidding away from the Gare du Nord, one dark greasy February morning before the shutters were down, Henrietta sat beside Miss Fisher (HP 1, emphasis added).

There are five prepositions in each of these sentences - in the second, there are four prepositional phrases even before the subject is introduced. Bowen's sentences are, as she said about her characters, "almost perpetually in transit ${ }^{25}$ ". For Bowen, the problem of language is intertwined with the problem (and necessity) of movement. Language is performative, a form of movement. "Speech", Bowen says, "is what the characters do to each other ${ }^{26 "}$. Her characters, she writes "are in transit

24. This is, of course, magnified by the magnanimous orphan at the center of Bowen's final novel, Eva Trout (see Paige Reynolds's “Colleen Modernism: Modernism's Afterlife in Irish Women's Writing”, Eire-Ireland 44, p. 3-4 (2009) for an incisive reading of that novel). There are hints of Eva's origins all over The House in Paris. Close to the end of the novel, the narrator, speaking of Leopold, muses, "A child knows what is fatal. The child at the back of the gun accident - is he always so ignorant?" (HP 248). This becomes the central question of Eva Trout's conclusion.

25. Elizabeth Bowen, "Pictures and Conversations." The Mulberry Tree, London, Vintage, 1999, p. 286.

26. Elizabeth Bowen, "Notes on Writing a Novel." The Mulberry Tree, London, Vintage, 1999, p. 41. 
consciously" ("Pictures" 287). They feel, they experience, by moving - and as fictional persons, they can only move through language. Bowen's Thirties novels are obsessed with the technology of movement, both linguistically and mechanically. In her essay, "Prosthetic Goddesses: Ambiguous Identities in the Age of Speed", Céline Magot aligns Bowen's novels with Futurism and Vorticism, examining how bodies in Bowen tend to merge with the machines that they use. Magot calls To The North "an allegory of speed ${ }^{27}$ ". The novel's very title is in motion, as are all of its characters. One of the novel's protagonists, Cecilia, "never seems to be happy when she is not in a train - unless, of course, she is motoring 28 " (TN 14).

Cecilia's sister-in-law, Emmeline, owns a travel agency whose motto is "Move Dangerously" (TN 25). One of Bowen's radical innocents, and an orphan, Emmeline does just this, driving at breakneck speed, without her glasses. Waiting for a flight to Paris, "Such an exalting idea of speed possessed Emmeline that she could hardly sit still and longed to pace to and fro" (TN 167). Possessed by the need to "move dangerously", this restless orphan - the first careerwoman in Bowen, by the way - strives to provide the same thrilling anxiety to her clients. She explains, "What everyone feels is that life, even travel, is losing its element of uncertainty; we try to supply that. We give clients their data: they have to use their own wits. 'Of course', we always say to them, 'you may not enjoy yourselves'” (TN 25). In this way, Emmeline's travel agency sounds like an analogue for modernist reading practices: the data is provided, but to interpret it, the reader has to use her own wits.

The brilliant set-piece on the airplane in To The North (which Valentine Cunningham calls literature's first example of air-mindedness), investigates the implications of new movement technology on language ${ }^{29}$. Unable to hear each other speak, Emmeline and her lover Markie pass notes to one another across the table. For Markie this means, "The indiscretions of letter-writing, the intimacies of speech were at once his" (TN 170). But the paper conversation, with Markie's admonition to Emmeline that he will not marry her, is overshadowed by Emmeline's own linkage of the movement of her travel and the movement of her plot, her relationship with the caddish Markie. In the plane, she thinks, "She was embarked, they were embarked together, no stop was possible; she could now turn back only by some unforeseen and violent deflection - by which her exact idea of personal honour became imperiled - from their set course" (TN 171). Emme-

27. Céline Magot, "Prosthetic goddesses: ambiguous identities in the age of speed", Textual Practice 27.1 (2013): 131.

28. This is reminiscent of Francie Montmorency's description of Lois in The Last September: "She is in such a hurry, so concentrated upon her hurry, so helpless. She is like someone being driven against time in a taxi to catch a train, jerking and jerking to help the taxi along and looking wildly out of the window at things going slowly past. She keeps hearing that final train go out without her" (Elizabeth Bowen, The Last September, New York, Anchor, 2000, p. 118. Hereafter, abbreviated TLS).

29. Valentine Cunningham, British Writers of the Thirties, Oxford, OUP, 1998. 
line and Markie's fraught relationship sounds a lot like our historical notion of the 1930s, a decade that seems an unstoppable movement toward violence, and indeed their relationship ends as the decade does, in a dramatic and undoubtedly fatal crash. The novel's conclusion doesn't write the crash, however, but leaves Emmeline and Markie speeding off into the dark, Emmeline's eyes shut behind the wheel. "Poor Emmeline", Bowen later remarked, "it was inevitable ${ }^{30 "}$.

One of the inevitabilities of travel is, of course, baggage - with all of its physical and emotional connotations. In "Elizabeth Bowen, Howards End and the Luggage of Modernity", Emily Ridge convincingly argues that luggage is the analogue for fiction in Bowen's work ${ }^{31}$. She contrasts this with EM Forster, for whom fiction was a house. In Bowen, Ridge argues, "luggage becomes emblematic of the search for a new kind of form" (111). Luggage encapsulates modernity as movement; displays Bowen's ambivalent relationship with literary tradition (as in, Forster's house); stands in for stylistic mobility, and overall, luggage questions the meaning of belonging. I will extend Ridge's argument by positing that the orphan child is the ultimate piece of baggage. As Henrietta thinks to herself in The House in Paris, "But we're children, people's belongings" (HP 55). The trouble is that the orphan child belongs to no one. Leftover (in literary terms, perhaps from the gothic novel), the orphan embodies at once both the past and the future. But being parentless, homeless, the orphan problematizes the present. "The Present" sections of The House in Paris focus on the day two half-orphans, Henrietta and Leopold, spend, coincidentally, in transit at Mme Fisher's gothic Parisian home. Eleven-year-old Henrietta's mother is dead (much to her embarrassment) and she is on her way from London to her grandmother in the south of France, dispatched overseas with a cerise cockade to identify her as she transfers, like a traveling box, from one chaperone to the next. Leopold is the illegitimate son of Karen and the dead Max. Raised in Italy by American adoptive parents, whom he hates, Leopold has come to Paris at the age of nine for a promised meeting with his mother. The meeting, heartbreakingly, does not come off, and Leopold spends the day waiting for something to happen - waiting, though he does not know it, in the very room where his father committed suicide before his conception was known. Unknowingly, in his little sailor suit, Leopold is the physical embodiment of illicit sexual desire, the residue of a hushed-up past, but also, as his mother hoped, the future of his father: "Why should Max leave nothing?" (HP 207).

Leopold's name deliberately links him to his literary antecedents, as well. With a Jewish father, he is the obvious literary offspring of modernism's most famous fictional Jew, Leopold Bloom, but instead of looking for a son, Bowen's Leopold

30. Victoria Glendinning, Elizabeth Bowen: Portrait of a Writer, (London, Weidenfeld and Nicholson, 1997, p. 86. 31. Emily Ridge, "Elizabeth Bowen, Howards End and the Luggage of Modernity", Textual Practice 27.1 (2013). 
plays the role of Stephen Dedalus, searching for a parent. He is the reverse of Bloom in another way, too. Both novels are framed in the course of a single day, but while Joyce's Leopold spends his day on the move, Bowen's Leopold spends the entire novel standing still. The form of the novel underscores this: by bracketing the story of Karen and Max's affair between the morning and afternoon of the day in Paris, Bowen brackets, as the novel specifies, "The Past" into the middle of "The Present". In other words, the discontinuous modernist form of the novel enacts the problem of Leopold himself: a relic of the past bracketed into the present ${ }^{32}$. This plot device also extends Leopold (and the reader's) wait for his mother by 150 pages while managing, simultaneously, to introduce her into the narrative, creating the impossible account that Leopold hoped his mother would give: the story of "what made me be" (HP 65). The narrator acknowledges that this account is only made possible by Karen's failure to arrive, and so indicates that the middle of the novel, the section called "The Past", is only the province of fiction: "Only there - in heaven or art, in that nowhere, on that plane - could Karen have told Leopold what had really been" (HP 66).

But what do we do while we wait for Karen's story? What does the orphan do while he waits for the story which sits between Naomi's twice repeated line, "Your mother is not coming; she cannot come" (HP 62, 213). The orphan boy is a piece of baggage who must wait for a new handler. And here he must wait, in Beckettian terms, for nothing to happen twice.

"I have got to be somewhere", Henrietta tells Leopold, "I can't just melt" (HP 53). "But where can you go", she asks him later, "if nobody knows you're born?" (HP 55). At once aligned with high modernism though the figure of Bloom and with the spectre of World War II, as a Jewish boy, with no family, alone on a train journey, Leopold embodies the nervous waiting many people felt in the 1930 s. He is a character left between - between literary histories, between families, between nations. In her essay "Late Modernism and the Politics of History", Jean Radford has noted that with the 1935 enactment of the Nuremberg Laws, Leopold "has something to be nervous about ${ }^{33}$ ". By making the wandering Jew into an orphan child, Bowen has altered the stakes: he cannot wander alone. He can only wait, as his mother waited, for something to happen to him.

In the end, something does happen. His mother's husband, Ray, arrives in her stead, possessed by the imprint this unseen little boy has left, like a ghost, on his

32. The "unspokendialogue" of Karen and Ray's marriage at the end of the novel is presented in dramatic form, reminiscent of the Circe chapter in Ulysses.

33. Jean Radford, "Late Modernism and the Politics of History," Women Writers of the 1930s: Gender, Politics and History. Ed. Maroula Joannou, Edinburgh, Edinburgh University Press, 1999. For more on Leopold's Jewishness, see Phyllis Lassner. British Women Writers of World War II, London, Macmillan, 1998 and Neil Corcoran, Elizabeth Bowen: The Enforced Return, Oxford, OUP, 2004. 
marriage. Recklessly crashing both societal and legal taboos, Ray arrives at the house in Paris, claims the boy, and heads with him to the Gare de Lyon to deposit Henrietta with her next baggage handler. In a passage decidedly un-realist in its point of view and tense shifts, Ray and Leopold contemplate their next move:

"All right," said Leopold. "Where are we going now?" Where are we going now? The station is sounding, resounding, full of steam caught on light and arches of dark air: a temple to the intention to go somewhere. Sustained sound in the shell of stone and steel, racket and running, impatience and purpose, make the soul stand still like a refugee, clutching all it has got, asking: "I am where?" You could live at a station, eating at the buffet, sleeping on the benches, buying your cigarettes, going nowhere next. The tramp inside Ray's clothes wanted to lie down here, put his cheek in his rolled coat, let trains keep on crashing out to Spain, Switzerland, Italy, let Paris wash like the sea at the foot of the ramp. And a boy ought to sleep anywhere, like a dog. But the stolen boy is too delicate. Standing there on thin legs, he keeps his eyes on your face. Where are we going? Where are we going now? (HP 267)

The novel ends with the two of them standing at the foot of the station ramp. As in The Death of the Heart and To the North, the ending is implied, not explicit. Ray and Leopold never actually leave the station. They are refugees of a literary history that knows that making it new is past but that the new new thing has yet to arrive. They keep their eyes on us; they demand our attention. They leave us wondering, "Where are we going now?" But the novel, like Ray, refuses to answer.

None of Bowen's orphan novels properly "answer" the question of the orphans at their centers. The violent deaths of Emmeline and Markie, Karen's dramatic and dreaded reunion with her son, Portia's unwilling return to Anna and Thomas - all these scenes are denied to the reader, left to his or her own imagination. Even Lois in The Last September is packed off to France before her fiancé is dead two weeks. The reader learns this from her aunt, who responds to an inquiry with a cryptic, "Oh, gone, you know... Tours. For her French, you know" (TLS 300). The reader, however, wouldn't know; Lois had never mentioned her French. But mourning the death of a British soldier in the middle of the Anglo-Irish War would make her less convenient than ever. So the orphan with the tendency to hide in the Danielstown box-room is boxed off herself, sent away for what may become permanent "Tours". Not long afterward, the house is burned by the IRA. This novel, populated by homeless Anglo-Irish professional visitors and their endless luggage, ends with the entire Naylor family as implied refugees, as their "door stood open hospitably upon a furnace" (TLS 303). 
If the Anglo-Irish were, for Bowen, the orphans and refugees of the 1920s, a less hospitable furnace would be prepared for the refugees pouring into England by the end of the next decade. Bowen's 1930s novels echo the rising anxiety of the "devil's decade" as it progresses, but in each of the novels, the reader is left in suspense at the end. The Death of the Heart concludes with the Quaynes' housekeeper, Matchett, preparing to knock at the door of the Karachi Hotel to fetch a Portia who feels, "I've got nowhere to be" (DH 377). Meanwhile, Matchett herself has "no idea" where she is, having got into a taxi without listening to where she was being sent ( $\mathrm{DH} 415)$. Matchett's anxious taxi ride, narrated in free indirect style from her own troubled thoughts - for "when at moments she thought, she thought in words. I don't know, I'm sure" - seems to foreshadow the doomed taxi ride that ends Bowen's World War II story, "The Demon Lover" (DH 413). In the 1941 story, the similarly prosaic Mrs. Drover's taxi driver takes off without her having "said where ${ }^{34}$ ". In The Death of the Heart, the driver unsettles Matchett but leaves her intact at the Karachi Hotel, though the novel refuses to resolve whether Anna and Thomas have "do[ne] the right thing" about Portia (DH 398). "The Demon Lover", on the other hand, ends with the sounds of Kathleen Drover "scream[ing] freely... as the taxi, accelerating without mercy, made off with her into the hinterland of dark streets" (CS 666).

The endings of Bowen's orphan novels of the 1930s mime their own characters' seeming inability to speak coherently about the world in which they live. Like Bowen's characteristic sentences, like her displaced orphans, these novels' endings are at once arrested and on the move. In Emmeline's car in St. John's Wood, at the foot of the station ramp in Paris, at the door of the Karachi Hotel, these novels leave their orphaned subjects on the verge of something happening. Perhaps their refusal to say what is next is akin to Emmeline's shutting her eyes behind the wheel, for the years to come, "accelerating without mercy" upon the 1930 s, were not the ending anyone wanted to tell.

34. Elizabeth Bowen, The Collected Stories, New York, Anchor, 2006, 666. Hereafter, CS. 